\title{
Socio-cultural and Policy Related Constraints to Women's Land Right: A Case Study from Gamo Highland, SW Ethiopia
}

\author{
Teshome Yirgu Bayu \\ Department of Geography and Environmental Study, Arba Minch University, Arba Minch, Ethiopia
}

Email address:

tebayu2013@gmail.com (T. Y. Bayu), teshomeyirgu_bayu@yahoo.co.in (T. Y. Bayu)

To cite this article:

Teshome Yirgu Bayu. Socio-cultural and Policy Related Constraints to Women's Land Right: A Case Study from Gamo Highland, SW Ethiopia. Humanities and Social Sciences. Vol. 3, No. 4, 2015, pp. 149-154. doi: 10.11648/j.hss.20150304.14

\begin{abstract}
Women are the most marginalized and disadvantaged group of society in relation to accessing and controlling land in rural Ethiopia. The study critically reviews and analyzes the status of rural women in access to and control over land in three purposefully selected rural kebeles of Gamo highlands, SNNPR on smallholder farmers. In the study mixed research approaches including qualitative and quantitative methods were used to collect and analyze data. Survey of 164 households mainly females were conducted administrating questionnaires in the quantitative methods. The qualitative method applied was group discussion and interviews and personal observation. In the study descriptive statistics and regression analysis were utilized. The findings clearly depicted that in the study area female headed households owned 0.52 ha farmland compared to 0.86 ha of their male counterpart, where the average holding at the national level and Gamo highland is 0.96 and 0.92 ha respectively. Though, Ethiopia's legal framework is progressive in its support to women's land rights, due to harmful customary practices, patriarchal orientation and traditional social norms towards female in Gamo highland female do not own and control rural land, and even inherit land from their family and death of husband. The study further noted that among sociocultural and institutional factors discriminatory cultural practices (60\%), low awareness of women on their land right (19.4\%), challenge of law enforcement (10.3\%) and women's position in the society $(4.7 \%)$ are the most dominant constraints that impedes women's land right in the study area. Moreover, in the study area women's are less represented in leadership positions and rural land administration council. Of the independent socioeconomic variables sex, educational status and family size are appeared to be statistically significant association with land ownership. Finally it is suggested that awareness creation campaign and proportional representation of women in decision making process and local land administration councils needs urgent response.
\end{abstract}

Keywords: Women's Land Right, Gender Equity, Households, Social Norms, Patriarchal Orientation

\section{Statement of the Problem}

Gamo highland is located in the Ethiopia's South most administrative zone Gamo Gofa, SNNP Region in the western escarpment of the great East African rift valley system. It lies between $6^{\circ} 8^{\prime} 55^{\prime \prime} \mathrm{N}$ to $6^{0} 25^{\prime} 30^{\prime \prime} \mathrm{N}$ latitude and $37^{\circ} 29^{\prime} 57^{\prime \prime} \mathrm{E}$ to $37^{\circ} 39^{\prime} 36^{\prime \prime} \mathrm{E}$ longitude. It is a vast mountain system covering partly nine districts, namely Kemba, Dera Malo, Bonke, Arba Minch Zuria, Dita,Kucha, Chencha, Mirab Abaya and Boreda.

Land is one of the most fundamental resources to women's living conditions, economic empowerment and, to some extent, their struggle for equity and equality. However, due to economic, legal, social, and cultural factors their rights to access and control land are weaker compared to their male counterpart.

In rural Ethiopia women constitute almost $50 \%$ of the population; as a result their contribution to Ethiopia's agriculture is paramount. According to central statistical agency CSA (2013/14), of the estimated 54.6 million total population in agricultural households, about $27 \%(49.5 \%)$ are women. Despite its significant size and contribution to economy, due to the patriarchal social norms and customary practices rural women in Ethiopia are the most vulnerable group of society (Tenaw et al. 2009). But significant gender inequalities can be found in peoples' access to key productive assets and services such as land, labor, financial services, water, rural infrastructure, technology, and other inputs. 
Available evidence indicates that the distribution of land ownership is heavily skewed toward men (Doss, 2006).

In Sub-Saharan Africa, unmarried women have little access to land because they are not allowed to inherit property while wives have better access to their husbands' land through marriage. Security of marriage thus becomes major requirement for security of tenure (Davison, 1988). Similarly, in Rural Ethiopia land is not only material and productive resource that enable livelihood of the rural community, but it is also an important symbolic resource that heavily influences status and identity. Moreover, it is deeply laden with cultural and spiritual meanings that are context and cultural specific.

Due to patriarchal orientation, in rural Ethiopia gender equality has not been achieved and women do not enjoy equal right with men in accessing and having control over land and effectively participate in public affairs (Teklu, 2005; Verma 2007). Thus Scio-economic and institutional constraints impede Ethiopian women's ability to exercise their rights and benefit from the growing economy. Various social norms related to lineage, marriage practice, and inheritance considerably affect women's rights with regards to access to and control of land. For instance, the patrilineal system of residence often operates to exclude women from controlling land (Adal, 2005). Though, there exists constitution and legislations that favors women's land use right in Ethiopia, female and women headed households due to socio-cultural barrier they are excluded from their land holding right.

The tenure system in Ethiopia has undergone numerous reforms over the centuries. For instance, prior to 1974 tenure systems failed to provide women with secure rights to land to the extent that women couldn't legally inherit (Tesfa, 2002). With the 1974 state change, the feudal tenurial arrangement was replaced by state owned type of land right of "Derg" regime. But during this period, female headed households were unable to benefit equally from the land allocation scheme (Ibid). The 1995 constitution of Ethiopia granted women to acquire, administer, control, use and transfer and inherit land ( FDRE, 1995). Though, women have policy support over farmland possession in present Ethiopia, in the study area, due to socio-cultural practices women didn't benefitted. Here women not only lost their land use rights, but also engaged in tiresome household and farming activities. As a result women are the most marginalized and disadvantaged part of the community. Thus, the study aimed to investigate the underlying causes and explore the status of unequal land use right of women in the study area.

\section{Study Area and Methodology}

\subsection{The Study Area}

Covering an area of $656.7 \mathrm{~km}^{2}$, the study area is located in the eastern part of Gamo highland at about $525 \mathrm{~km}$ southwest of Addis Ababa. It is located between $6^{0} 08^{\prime} \mathrm{N}$ to $6^{0} 25^{\prime} \mathrm{N}$ latitude and $37^{\circ} 20^{\prime} \mathrm{E}$ to $37^{\circ} 40^{\prime} \mathrm{E}$ longitude. In the study six sample Peasant Associations were considered, namely Giyasa, Gana Kare, Merzo, Mesho, Boyena Topa and Ho'o kebele (Figure 1). Physically, it has rugged terrain with an altitude ranging between $2400 \mathrm{~m}$ and $4207 \mathrm{~m}$ asl.

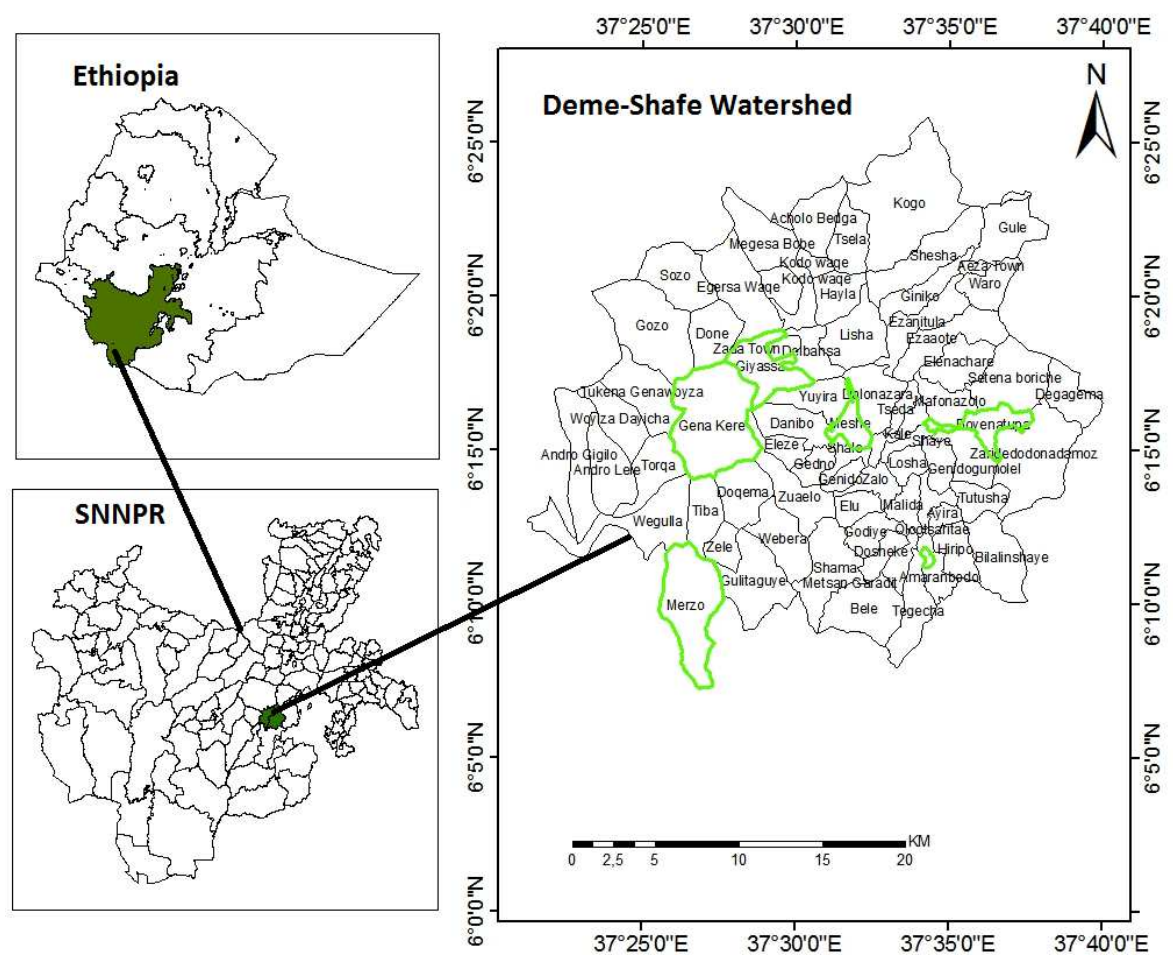

Fig. 1. location map of upper reaches of Deme-Shafe watershed, Gamo highland. 
September. The mean annual rainfall of the area varies from 1100 to $1300 \mathrm{~mm}$, while the average minimum and maximum temperature of the area is $18^{\circ} \mathrm{c}$ and $23^{\circ} \mathrm{C}$, respectively. Gamo highland is among the earlier inhabited and populous part in the Ethiopian mountain system, where natural vegetation is severely depleted and farm sizes are extremely marginal. In the mountain system mountain grass, high altitude vegetation and remnant forest fetches in some remote localities are dominant vegetation cover.

The per capita farm holding in the area is less than 0.25 hectare, it apparent to imagine their livelihood with the increasing rural population $(2.7 \%)$ and marginal and fragile land resource.

\subsection{Data acquisition and Method of Analysis}

\subsubsection{Research Design and Data Sources}

This research employed survey research design to collect and analyze data. Data required for the study was collected from both primary and secondary sources. The primary data was collected through household survey and focus group discussion. Secondary data was obtained from Central Statistical bulletin reports, and Gamo Gofa zone office of agriculture and rural development office. The research applied both quantitative and qualitative methods to clarify concepts, descriptions and measures to demonstrate implications of the issue under question.

\subsubsection{Sample Size Determination}

In the study two stages of sampling design were used to determine sample kebeles and sample household heads. In this case six sample kebeles were purposefully selected based on the large number of female headed households there. Selected kebele are Mesho, Boyena Tope, Giyasa, Gana kare, Merzo and Ho'o.

Selection of sample household heads was determined by using the formula after Lewis (1997). i.e., $\mathrm{n}=(\mathrm{Z} \alpha /$ 2) $2 p(1-p) / d 2$ Where $n$ is the desired sample size (when the population is less than 10,000).

$\mathrm{Z} \alpha / 2$ is the standard normal deviate at the required (95\%) confidence limit (1.96).

$\mathrm{p}$ is 0.145 (contingency for non-response rate or Proportion of the target population to be included in the sample).

$\mathrm{q}$ is $1-\mathrm{p}(1-0.145=0.855) ; \mathrm{d}$ is the level of statistical accuracy (margin of error) set usually at 0.05 and $\mathrm{N}$ - is the total number of the household heads

Using the above formulas, the desired sample size (n) is calculated as follows:

$$
\begin{array}{ll} 
& \mathrm{n}=(\mathrm{Z} \alpha / 2)^{2} \mathrm{p}(1-\mathrm{p}) / \mathrm{d}^{2} \\
\text { Therefore } & \mathrm{n}=(1.96)^{2}(0.145 * 0.855) /(0.05)^{2}= \\
190 &
\end{array}
$$

Substituting the value of $\mathrm{n}$ (190) in the second formula the actual sample household number is calculated as follows:

$$
\mathrm{nf}=\frac{n}{1+\frac{n}{N}}=\frac{190}{1+\frac{190}{3620}}=164 \text { sample size }
$$

In the study, 164 sample household heads were selected. The selection of sample household heads was made possible by arranging the household heads names in each PA alphabetically. Then by using systematic random sample techniques every $20^{\text {th }}$ household heads were proportionally selected from each sample kebele.

\subsubsection{Instruments of Data Collection and Data Analysis Techniques}

During data collection, all sample household heads were interviewed using a structured survey questionnaire. In addition, Key informant interview and focus group discussion were held with household heads and village elders and land administration officials. In the study both qualitative and quantitative data analysis techniques were utilized. In the qualitative analysis narrations and description of observed facts were discussed. Furthermore, descriptive statistics and regression models were utilized to analyze quantitative data.

\section{Result and Discussion}

\subsection{Socio-cultural Constraints}

Though Federal constitution (art.35 (4)) explicitly prohibits regulations and customary practices that discriminate land use right against women; in the study area women are not beneficiaries of the rules. This is due to their economic dependence, low level education and social position and above all socio cultural and institutional constraints. Therefore, gender roles, primarily informed by a patriarchal orientation, not only affect their constitutional land use rights but also limit their ability to effectively participate in public affairs. For instance, the study showed that about $60 \%$ of the households in the study area rated discriminatory cultural norms as the major constraint impedes women land right (Table 1). According to survey findings the discrimination against women further extended to allocation of marginal and smaller plots.

It was clearly revealed from the survey finding that in the study area female headed households on an average owned 0.52 ha farmland as compared to 0.86 ha for the male counterparts. As stated in Kumar and Quisumbing (2010) the national household farm size for female and male was 1.7 ha and 2.2 ha respectively. The most common inheritance system in the study area is patrilineal, where by succession and inheritance of property are determined through male line (i.e., only sons inherit land from the family plots). Because of the customary influences, daughters are prevented from inheriting family land. This was developed from the expectation that after marriage young women become part of another family.

Women's ability to assert their land rights and to benefit from land certification depends on women's awareness of their land right, their ability to invoke such rights. The study data revealed that $19.4 \%$ of the respondents at the overall level felt that low level of awareness to their legal land right have contributed the female households to be disadvantaged in all aspects of their livelihood. While considering their 
awareness at kebele level respondents in Tegecha kebele are relatively well awared than the other two study kebeles (Table 1). It is true that that in most patrilineal society like the study community, male household heads have got better social exposure and expected to have better access to customary and statutory laws. In regards to access to information, preliminary study conducted in Ethiopia on policy reform towards gender equity indicated a significant disparity between men and women (Kumar and Quisumbing, 2010). A similar study conducted in Oromiya and SNNP Regional States found that women have limited knowledge of their property rights under the legal system and that gaps in the legal system prevent the inheritance and co-ownership of property acquired in marriage (Holden and Tefera 2008).

Table 1. socio-cultural \& institutional constraints impede women's land right, 2014.

\begin{tabular}{|c|c|c|c|c|}
\hline \multirow{2}{*}{ Constraints in the households } & \multicolumn{4}{|l|}{ Kebele } \\
\hline & Mesh \% & Gule \% & Tegecha $\%$ & Mean \% \\
\hline Discriminatory cultural practices & 64 & 68 & 48 & 60 \\
\hline Low awareness of women on their land rights & 17 & 12 & 29 & 19.4 \\
\hline Discriminatory application of land law or enforcement challenges & 8 & 12 & 11 & 10.3 \\
\hline Lack of support by local government & 2 & 1 & - & 1 \\
\hline Under representation in leadership role such as land administration council and in kebele posts & 1 & 2 & 1 & 1.3 \\
\hline Polygamous relationship & 2 & 1 & 1 & 1.3 \\
\hline Women's reluctance to claim their rights & 4 & 2 & 2 & 2.7 \\
\hline
\end{tabular}

Source: survey data, 2014

Discriminatory application of land law by village elders during inheritance and partition of property during divorce, and enforcement challenges by kebele administration are considered as the third most rated $(10.3 \%)$ constrain in the area. Here due to their low social exposure and engagement in tiresome farm and household duties women have low knowhow about their land rights. A similar study conducted in the Northern Ethiopia by Adal (2005) also confirms the discriminatory application of law and socio-cultural practices that precluded women from exercising their right. Women's position within the household or society especially in the traditional communities like the study population plays a significant role in hindering their rights and benefits from the land resource. As a result it was rated by respondents as the fourth $(4.7 \%)$ most influential variable affecting women's land right.

Due to cultural influences women themselves may be reluctant to become publicly involved in political activities and community organizations for reasons like inexperience in public speaking and participation and lack of knowledge about how legal matters function. Thus in the study area, women reluctance to claim their legal land rights could be rated as the fifth most rated constraint as reported by $2.7 \%$ of the households. Even women knew that they have rights in front of law they don't claim their rights due to their preference to have long-term social bondage with their brothers and other male family members.

Federal constitution accords women equal rights with men in regards to the use, transfer, administration and control overland (art. 35(7)). But in the study locality women are not benefited practically from the provisions due to legislation related problems. This is because the legislation gives prevailing patrilineal inheritance system; which compromise wives right to land as they are not likely to inherit land from their natal families. In addition, discriminatory application of land law, enforcement challenges and high illiteracy rate often preclude women from exercising their rights. In addition due to their inferior social recognition, women are not well treated in front of village elders and in some instances even in front of village land administration council (key informant discussion result). Discussion result further showed that land grabbing by male relatives following the death of husband are also the common experience among some male family members in chencha district. In this regard, the survey result confirmed the presence of enforcement challenges of land law as the third most rated land right constraint $(10.3 \%)$.

Polygamous relationship and under representation of women in land administration council are identified as the other challenges of women to exercise land right in their localities (rated by less than $1.5 \%$ of the respondents). Though, polygamy is not permitted by law, in the study area polygamous marriage is wide spread practice. Some study revealed that in Ethiopia polygamy marriage estimated $6.5 \%$ of marriages in national level (Adal 2005). In Chencha district, men with larger and fragmented farms prefer to marry more than one wife. Focus group discussion result showed that the husband usually divide the available land among his wives and plough for each of them. But further management of the cropland was left to wives and children. In the study area, representation of women in land administration council and other related leadership role was minimal. The presence of female members in decision making processes can benefit women for fair resource allocation. A study showed that women representation in the land administration councils corresponds with a heighted expectation of equitable distribution of assets upon divorce (Kumar and Quisumbing, 2010).

\subsection{Land and Registration Certification}

The issuance of land use certificate is assumed to increase the sense of ownership and security over their possession. Surveyed data showed that $73 \%$ of the study households received land holding certificate. Discussion with district Land Administration experts also confirmed this fact that 
once they have reported the size and number of their holdings they are unable to sale their holding. Key informant discussion result revealed that though sell of the land is prohibited by law, farmers are continuously selling their holding by the name of "long term lease."

During the pilot survey, the researcher observed that women and men farmers are unaware of the motive of the government behind the land certification and registration program and are unable to explain their legal land rights. In line with this, a study conducted in Dessie Zuria district (Amhara national regional state) revealed that awareness of the peasants about the Federal and Regional rural land proclamations is very low (Dessalegn 2009). The same source concluded that the knowledge of majority women about the issuance of the certificate is even lower than their men counterpart.

During group discussion women replied that their husbands are reluctant to recognize their land rights. Furthermore, survey data revealed that male households in polygamous marriage have not in whole heartedly welcomed and accepted women's equal land rights. When wives raised their land rights, their husband consider it as a challenge to their traditional power in the family. Hence according to my informant, Ms. Endo Tema that arguments and counter arguments by house wives may entail a negative consequence in the normal household relationship.

In the study area, widow household's accounts $36 \%$ of the total study households. As a tradition after death of male household head, household plots are registered by the name of son, except under some circumstances where the son is too young. According to my informant, Ms. Endo Tema when the land certificate refers the name of his mother (widow), in practice it is the son who is considered to be the owner of the holdings. Therefore form the finding it is possible to suggest that in the traditional community like the study population, the implementation and recognition of customary practices occupy the dominant position over the statutory rights. According to District Land Administration expert, such an experience will be eliminated if women are well represented in land administration councils. As reported by the same source that married women and female household heads are less involved in implementing land registration and certification program. This shows that local tradition is still a major impediment against women involvement and participation in government initiated program that benefits their interest.

A study conducted in four regions of Ethiopia revealed that the land registration and certification program implemented on these regions did not seem to have overcome the preexisting gender bias practices (Deininger et al. 2007). According to Tesfaye (2003), rural female household heads do not have equitable access to land and agricultural resources. The same sources further noted that they are less involved in development activities and have low decision making power. Their labor contribution to agricultural sector is invisible because of the gender division of labor in communities. Survey data revealed that compared to men, women farm plots are smaller, more fragmented and are less likely to improve, or dispose of land.

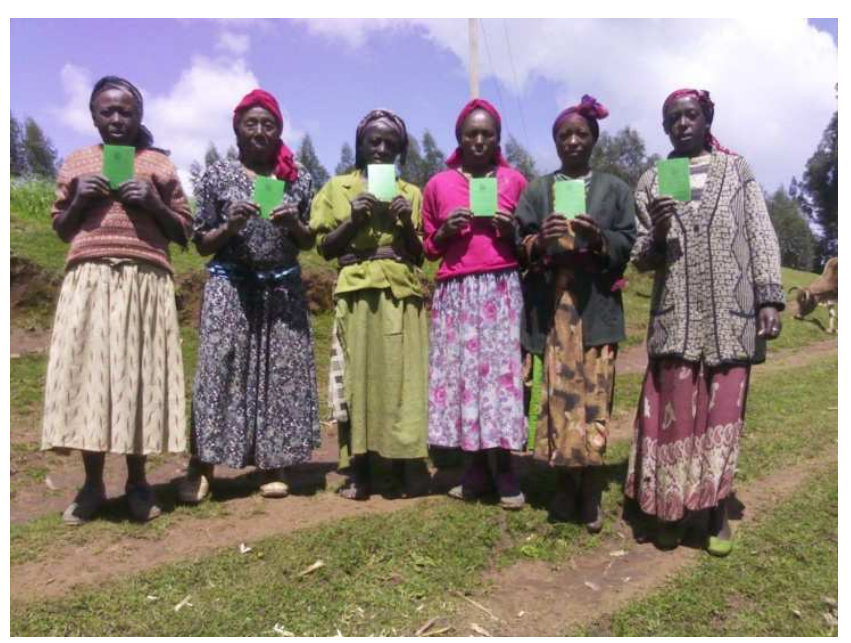

Fig. 2. women headed households with their land use certificate, Chencha district, 2014.

According to District land administration source, after land certification program, each woman in the polygamous marriage was issued separate joint holding certificate with her husband. Such experience would ensure polygamous women a sense of security over their holding like their counterpart in the monogamous marriage. Under such circumstances, man have more land access rights and enjoy the share of more agricultural produces from plots they jointly hold with their wives. A study conducted in Shshemene and Arsi Negele areas of Oromiya and in Wondo Genet and Wolayta areas of Southern Nations, Nationalities and Peoples region, SNNPR showed that women in polygamous relationship have lower expectation about the share of land they keep after divorce than other wives even after they get the joint holding certificates (Holden and Tewodros 2008).

\section{Conclusion}

Land is one of the most fundamental resources to women's living conditions, economic empowerment and, to some extent, their struggle for equity and equality. However, due to economic, legal, social and cultural factors their rights to access, control and transfer land are weaker compared to those of men. In rural Ethiopia women constitute almost half of the population. Among those who are engaged in productive agricultural activities, women constitute almost $49.6 \%$ of the total population. Despite the significant contribution to the economy, due to customary bias women's are prohibited from exercising their statutory land use rights. The study shows that an effective implementation of women's right to rural land is mainly attributed to the negative attitudes and harmful practices which deny a women's right to own, administer property and control the rural land. In addition, lack of legal awareness of their rights and lengthy trial procedures in case of dispute between 
spouses or husband relatives during the death of male household heads are the other prominent constraint to women. Moreover, group discussion results confirmed that low level of education, weak and dependent economic status of women are considered to be the other challenges which affects women land rights in the area. Above all customary laws and practices have serious impacts on women's land right. Therefore, in order to positively address women's land right constraints empowering women in varying land related rights and equitable representation of women in rural land administration council need urgent attention.

\section{References}

[1] Adal Yigremew (2005). "Rural Women's Access to Land in Ethiopia." Addis Ababa: Forum for Social Studies.

[2] Davison J., (1988). Land and Women's Agricultural Production: The Context in Agriculture, Women and Land The African Experience. J Davison (ed), West view Press, Bould and London.

[3] Daniel Ayalew Ali, Stein Holden and Jaap Zevenbergen, (2007). Recertification in Ethiopia: Process, initial impact, and implications for other African countries.

[4] Dessalegn Rahmato (2009). The Peasant and the State: Studies in Agrarian Change in Ethiopia (1950's-2000's). Addis Ababa: Addis Ababa University Press.

[5] Doss Chery (2006). "The effect of interschool property ownership on expenditure patterns in Ghana." Journal of African Economist. 15 (1). 149-180.

[6] Federal Democratic Republic of Ethiopia, FDRE, (1995). Federal Democratic Republic of Ethiopia. Proclamation No. 1/1995 Proclamation of the Constitution of the Federal Democratic Republic of Ethiopia, Addis Ababa.
[7] Holden Stein and TeferaTewodros (2008). "From Being Property of Men to Becoming Equal Owners? Early Impact of Land Registration and Certification on Women in Southern Ethiopia." Nairobi: UNHABITAT.

[8] Kumar Neha and Quisumbing A (2010). "Policy Reform Towards Gender Equality in Ethiopia: Little by Little the Egg Begins to Walk." Washington DC: Intentional Food Policy Research Institute.

[9] Lewis B (1997). Doing your research project, A guide for first-time researchers in education and social science, $3^{\text {rd }}$ Edition open university press maidenhead Philadelphia, USA.

[10] Teklu Askale (2005) "Research Report 4: Land Registration and Women's Land Rights in Amhara Region, Ethiopia." London: International Institute for Environment and Development.

[11] Tenaw Shimelles, Zahidul Islam, and Tuulikki Parviainen (2009). "Effects of land tenure and property rights on agricultural productivity in Ethiopia, Nambia, and Bangladesh." Helsinki: University of Helsinki.

[12] Tesfa Hadera (2002). "Women and Land Rights in Ethiopia: A Comparative Study of Two community in Tigray and Oromiya Regional States." Kampala: Eastern African Sub- Regional Support Initiative for the Advancement of Women (EASSI).

[13] Tesfaye Beshah (2003). Understanding Farmers: Explaining Soil and Water Conservation in Konso, Wolaita, and Wollo, Ethiopia. The Netherlands: Wageningen University and Research Center. PhD Dissertation. Retrieved on 05-March2010, from http://library.wur.nl/ebooks/1676777.pdf.

[14] Verma Ritu (2007). "Without Land You are Nobody": Critical Dimensions of Women's Access to Land and Relations in Tenure in East Africa Nairobi. Ottawa: IDRC. 